\title{
Mainstreaming Horticulture into Public Education: Introduction to the Colloquium
}

\author{
Mary Lewnes Albrecht \\ Department of Horticulture, Kansas State University, Manhattan, KS 66506-4002
}

\begin{abstract}
Horticulture programs across the United States experienced enrollment increases that peaked during the mid-1970s. Then, enrollments decreased almost as rapidly as they had increased. During the late 1960s and early 1970s, many events contributed to increased enrollments. The Baby Boom generation reached college age. Governmentsupported student aid programs were established. Young men attended college to avoid the military draft. An increased awareness of the problems facing our environment culminated in the first Earth Day celebration on 22 Apr. 1970. The civil rights and women's rights movements of the 1960s allowed an influx from segments of our population that had not previously been encouraged to attend college.

However, during the late 1970s and into the 1980s, enrollments began to drop. What contributed to the decline? A decrease in the number of students graduating from high school meant there were just fewer students. Student aid programs eroded during the 8 years of the Reagan administration. Double-digit inflation financially prohibited many students from attending college. The farm crisis of the mid1980s, which put all of agriculture in a perceived crisis situation, hurt the public image of career opportunities in agriculture. And there was a shift in attitude that created the "me generation"-a shift from helping others and the environment. The number of active civil rights and women's rights movements also declined, as did the number of
\end{abstract}

volunteers for organizations such as the Peace Corps. From the chaos of the social riots of the late 1960s and campus unrest of the early 1970 s, the "yuppie generation" was born.

All is not bleak. Today we have ways to integrate horticulture into public education. We need to capitalize on recent events that have put the environment, health, and nutrition in the headlines. Events such as the Islip, Long Island, garbage barge that no one wanted; medical wastes washing up on beaches in the eastern United States; the Exxon Valdez oil spill; the 20th anniversary of Earth Day; the concern over rapidly filling landfills; mandatory recycling programs in many states; consumer pressure to rid McDonalds of polystyrene containers; and the regreening of the world all lead toward a greater need for horticulture.

The problem is how do we let people know about horticulture? We know that horticulture has a direct impact on the quality of life and the environment. Many high school science fair projects entered as botany or biology projects are really horticulture projects. The Floriculture Education Working Group has asked the question, "Can Mr. Rogers say horticulture?" We concluded that the public did not have a clear idea of what horticulture is all about. The goal of this colloquium is to achieve an understanding of public science education and learn how we can interface with public education. 